\title{
Affective Resonance: \\ On the Uses and Abuses of Music In and For Philosophy
}

\author{
ROBIN JAMES
}

Affect is often presented as an alternative to visual and/or representational theories, phenomenologies, and experiences. For example, Jasbir Puar contrasts the "representational" logic of "intersectionality" with the affective logic of assemblage. ${ }^{1}$ Similarly, Linda Alcoff argues that the "visual" aspects of identity are grounded in corporeal, sensuous horizons. ${ }^{2}$ The study of affect, both in gender studies and especially in philosophy, has largely ignored musicthough this is, thankfully, beginning to change. ${ }^{3}$ Even scholars working with and through Deleuze, who does actually talk about music, often either overlook his work on music, or use "music" in a very general way, as a metaphor abstracted from musical practices or works. ${ }^{4}$ These oversights are surprising, because when philosophers who are not explicitly working on music do appeal to music, they often use music as a metaphor for affect. ${ }^{5}$ Music, like affect, emotion, or implicit understanding, is the Other of philosophy, at least as it is conventionally defined and practiced. For philosophers with little formal training or practical experience in music, "music" often serves as a metaphor for all that philosophy isn't: affective, sensuous, embodied, feminine, etc. Or, because we don't know how to put our experiences of music into propositional form, it seems to be purely affective, implicit, sensuous experience. ${ }^{6}$ Music can seem almost magical, because people without some sort of background in music (either in performance or in theory/history) generally lack the technical skills and concepts to analyze a piece of music and 
explain how and why it works the way it does. If we don't understand all the work that goes into making music - from the epistemic frames that organize music/noise distinctions, to the logic of specific compositional strategies (like tonality or ragas), to more practical matters like audio engineering or how to play the piano - it might appear to affect us in relatively immediate ways. Our experiences of music are certainly affective, but music is not magical, nonpropositionalizable, or extra-logical. If it were, then it would be indistinguishable from noise or sound. So, rather than treating both music and affect as philosophy's Other, it would be better to augment our philosophical analyses with the tools of musicology and music theory, so we can study exactly how musical affect works, and use this as the basis for philosophical reflection.

In this article, I am interested in both how music is used as a metaphor for affect, and how actual music (practices, theories, works) can help us understand the political dimensions of affect. Taking Jean-Luc Nancy's Listening as an example of philosophical work that theorizes affect, broadly construed through musical metaphors, I argue that working from overly-abstract concepts of music can lead even the best of us to significant philosophical problems. I treat music as more than just a metaphor, and compare Nancy's theory of music to real musical theories and practices. Following Nancy's musical metaphors all the way through clarifies several potential political problems with his theory, and why they are problems. First, Nancy's concept of listening normalizes and naturalizes maleness/masculinity. Second, because it idealizes a homophonic texture in which all subsidiary or "different" voices are recognized only insofar as they assimilate to and support a primary voice, his "resonant" politics is classically liberal multiculturalism, which values "difference" as a way to re-center whiteness and patriarchy. If these problems are consistent with the rest of Nancy's work, then taking music seriously contributes to a more fundamental philosophical critique; if these problems are 
inconsistent with the rest of his work, then this inconsistency evinces the dangers of taking music less than seriously. I will leave this question of (in)consistency open for Nancy scholars to address, so that I can stay focused on the role of music in theories of affect and the politics of difference.

One could argue that because Nancy wasn't using music as anything more than a metaphor, we neither need nor should take music seriously. This argument is wrong; it is always better, politically and philosophically, to start from actual music. When we treat music as a metaphor, when we don't ground our study of music in musical practices, works, and theories, "music" just becomes a mirror of whatever assumptions and biases we already have. In Listening, Nancy's use of music leads him to trade in some patriarchal stereotypes about femininity_-stereotypes and biases one hopes he would otherwise want to avoid. If we're interested in music and musical affect, we have to start from, or at least include, analyses of music. This means that we will have to learn some of the technical and practical tools that music scholars have, or maybe, work with music scholars. Such expertise and collaboration outside philosophy is common in work in the philosophy of science, aesthetics, applied ethics, and political philosophy, just to name a few subfields. In order to theorize affect, we have to study it; because affect is a concrete, empirical thing, we will need some tools and methods for analyzing these non-abstract, extra-philosophical phenomena.

Along these lines, I use R\&B/electropop singer Kelis's 2010 single "Acapella” (sic) to develop an alternative account of music, affect, and the politics of difference. It is not surprising that a song titled "Acapella" is about accompaniment (singing or being with others). The organizing metaphor in this song is not resonance, but polyrhythm—specifically, the irreducible difference in meter between a mother's heartbeat and her foetus's or child's heartbeat. ${ }^{7}$ Unlike 
Nancy, who treats the womb as a site of lost affective immediacy (which is recovered in resonance), Kelis's womb is a venue for irreducible, unassimilable difference. In Kelis's song, affect does not return us to ourselves, or unify us across differences; rather, affect is a dimension where we are here attuned to and dependent on others, and where differences multiply exponentially, irresolvable into any sort of unity.

Now that I've sketched out my basic argument, I will, in the next section, lay out Nancy's theories of (a) listening as attunement to affect and (b) resonance as structure of affective experience.

\section{Affect and Musical Listening}

In Listening, Jean-Luc Nancy (a) argues that phenomenology has been ocular- and logocentric to the exclusion of the aural and affective, and (b) develops a notion of affective listening that he then uses as a theoretical model. Nancy's text revolves around two key concepts: listening (écouter) and resonance (renvoi). Listening is the practice or the mode of attention; resonance is the phenomenon perceived/examined by listening. He uses echo or "resonance" as a metaphor for affect. One listens to the resonance of one's own eardrums: "on s'écoute," so to speak. $^{8}$ For Nancy, this self-referential, auto-poetic return is an echo to which Western philosophy has, he argues, become increasingly deaf. In Listening, Nancy assumes the Orphean task of recovering philosophy's lost Eurydice - the echo-like "resonance" that is obscured in philosophy's privileging of hearing (in the sense of entendre) over listening (in the sense of écouter). 


\section{(a) Listening}

According to Nancy, "to be" listening (écouter) is fundamentally different than "to be" hearing-understanding (entendre), and thus distinct from traditional Western ontologies (5). Hearing is the apprehension of a content, a "hearing say ... regardless of whether the sound perceived was a word or not" (6). One hears/understands the symbolic content of a sound. Listening is the attempt "to capture or surprise the sonority rather than the message" (5). To adopt some Kristevan terms, if one hears the symbolic message, one listens to the semiotic sonority (note also how this formulation implies that "hearing" is somewhat passive compared to "listening to," with its connotations of working or actively orienting oneself towards sound). ${ }^{9}$ According to Kristeva, the symbolic is the literal or verbal dimension of linguistic meaning (signifiers and signifieds), and the semiotic is the inflective dimension of linguistic meaning (tones, articulations, non-verbal sounds). ${ }^{10}$ If we hear words but listen to "what sounds from a human throat without being language" (Nancy 22), then it is precisely the semiotic to which we "listen." For all their apparent differences, the semiotic and the symbolic ultimately emerge and are articulated through one another. Similarly, Nancy does not view listening as opposed to or incompatible with hearing/understanding. To be listening is not to be outside or beyond meaning, but "to be on the edge of meaning, or in an edgy meaning of extremity ... as a resonant meaning, a meaning whose sense is supposed to be found in resonance, and only in resonance" (7). If hearing is attention to meaning-content, then listening is attention to affective resonance; to be listening is to perceive-and, even, to be-affect. In this sense then, even though the book is titled Listening, the concept of resonance does most of the work in this text. 


\section{(b) Resonance (Renvoi), Sound's Affective Rebound}

As Nancy defines it, resonance is quite literally "a presence 'on the rebound,' in a return [renvoi] from one element to the other ... all sonorous presence is thus made of a complex of returns [renvois] whose binding is the resonance or 'sonance' of sound" (15-16). Sound rebounds: re-bound is both return or repetition and a binding or conjoining. To rebound is to repeatedly join together in a way that creates "unity in and of diversity ... as much as [...] a diversity or divergence of and in unity" (18). This unity-in-diversity is possible because resonance links or binds things by playing them off one another; each element is a discernable yet integral part of a greater composition. Resonance unfolds according to the play of what acoustics distinguishes as its components (volume, length, intensity, attack, harmonics, partials, long-distance noises, etc.) and whose major characteristic is not to form merely the results of an abstract decomposition of the concrete phenomenon, but just as actually to play some against others in this phenomenon, in such a way that sound sounds or resounds always beyond a simple opposition between consonance and dissonance, being made of an intimate harmony and disharmony among its parts (15; emphasis mine).

Nancy uses acoustics - specifically, the overtone series - to illustrate the way in which resonance puts a multiplicity into play and thereby produces unity-in-diversity/diversity-in-unity. Every tone is composed of a primary "tone" and a series of "overtones": if the primary tone is the first scale degree, then the first overtone is an octave above the primary tone, and the subsequent overtones increase by a fifth, a fourth, a major third, a minor third, etc. ${ }^{11}$ It is more or less impossible to hear a "pure" tone sans overtones, because "sound sounds" only as the play or resonance of overtones. What we hear as a pitch is in fact the interplay, the unity-in- 
difference/difference-in-unity of overtones: each sound is a harmony and disharmony among its parts.

"To be" listening is to be structured by affect as a resonant rebound, i.e., as a unity-indiversity/diversity-in-unity. The renvoi returns the listener to himself (my use of gendered language is intentional; as I argue below, Nancy's listener is presumptively masculine) via affect. Or, more precisely, the renvoi returns the listener's capacity for affect, which hearing (philosophical logos) has trained him to ignore. Along these lines, Nancy claims that

perhaps it is necessary that sense not be content to make sense (or to be logos), but that it want also to resound. My whole proposal will revolve around such a fundamental resonance, even around a resonance as a foundation, as a first or last profundity of 'sense' itself (or of truth). (6)

According to Nancy, language (which we hear) is somehow lacking (and thus alienating us from the fullness of experience), and we need to turn to some more fundamental form of expression to overcome this alienation and get in touch with a deeper, more profound stratum of experience. Hearing trains us to ignore the affective dimensions of our own embodied experience; listening tunes us into affect, and in re-turning us to affect, return us to ourselves. To be listening is to attend to one's affective life, or life as affect.

It is somewhat inaccurate to refer to resonance as a structure of subjectivity, because Nancy uses this concept to confound conventional subject/object distinctions. The sonorous body "is always at once the body that responds and my body as a listener where that resounds, or that resounds with it" (70). The listener both resonates and perceives his own resonance. "Sound ... spreads out in space, where it resounds while still resounding 'in me,' as we say (we will return to this 'inside' of the subject; we will return to nothing but that)" (7). As the preceding sentence suggests, this return-to-self (that constitutes the very self to which it 'returns') is the most 
distinctive and important feature of "resonance." Somewhat like the Foucaultian subject that creates itself by reflecting on and referring to itself in confession, Nancy's resonant subject consists in

an infinite referral [renvoi], since it refers to something (itself) that is nothing outside of the referral ... a subject, something (itself) that identifies itself by resonating from self to self, in itself and for itself, hence outside of itself, at once the same as and other than itself, one in the echo of the other. (9)

Resonance is a movement both outward and inward, a gesture that is intensive and exstatic/ecstatic. "Resolved into vibrations that both return it to itself and place it outside itself" (8), the listener is both subject and object of these affective vibrations; they are both inside and outside him, he is their cause, but he is also affected by them.

Interestingly, by positioning the listener as both subject and object of listening, both alienated from and reunited with itself, Nancy circumvents many of the problems male artists face when subjected to the (hetero) "male gaze." As Laura Mulvey famously argued, Western aesthetics assume a normatively masculine subject who takes pleasure in looking at a feminized object. Western aesthetics functions by situating "woman as object, man as bearer of the look" (Mulvey 837). This poses a problem for male performers and male spectators: what happens when men are both objects and bearers of "the look"? What happens is a lot of homosocial anxiety: men don't want to be seen as feminized objects, nor as taking pleasure in gazing at other men (this is why male performers tend to exhibit hypermasculine persona - think of hair metal bands singing about strippers and motorcycles, or the more recent "no homo" idiom in hip hop). ${ }^{12}$ Nancy differentiates "the gaze" from "listening" in a way that circumvents this problem and allows male artists' authority and heterosexuality to remain unquestioned. He argues: "In terms of the gaze, the subject is referred back to itself as an object. In terms of listening, it is, in a 
way, to itself that the subject refers or refers back" (9). According to Nancy, the look always and only objectifies: to look at is to objectify. ${ }^{13}$ Listening, however, subjectifies-it is the very source and structure of the "self" as such. In blurring the subject/object distinction, Nancy's theory of resonance allows the affectively resonant body to which one listens-the object of listening - to avoid objectification and its implications: passivity, serving as the source of others' scopophilic or audiophilic pleasure-i.e., feminization. ${ }^{14}$

Nancy clearly states that resonance or sonority is feminine/feminized. He contrasts the gaze, which is externalized, with listening, which is internalized: "Why, in the case of the ear, is there withdrawal and turning inward, a making resonant, but in the case of the eye, there is manifestation and display, a making evident?" (3). Freud and Irigaray contrast the visibility and externality of male genitalia with the non-visibility and internality of female genitalia. ${ }^{15}$ Thus, to be "visible" is to be male/masculine, and to be "resonant," to experience "acoustic penetration" (Nancy 3), is to be female/feminized. This gendering is also evident in Nancy's related distinction between "reflection," which "requires a reflective surface" or object, and "resonance," which is "inside of sound itself" (Szendy x). To reflect is to mimetically repeat another's action; lacking autonomy, reflections, like the mythic Echo, have no "voice" of their own. Notably, Irigaray argues that patriarchy limits women to mirroring or reflecting normative masculinity, thereby effectively silencing them as women. ${ }^{16}$ To resonate, however, is to speak for oneself according to Nancy: "a sonorous body that is struck returns the blow by the sound that is the vibration of the blow itself" (quotation in Szendy $\mathrm{x}$ ). The language of "returning blows" calls on the violence and aggression attributed to idealized masculinity. For Nancy, Echo is not a passive, helpless female voice that can't even speak for herself, but a self-made sound: "the echo is made by making itself heard" (Nancy 8-9). Because the listener retains the 
normatively masculine privileges of agency and authority, he gains access to the stereotypically feminized experiences of being affected by or acted upon while avoiding the denigration and marginalization that go with these experiences when they are attributed to women.

Nancy uses the concept of "musical listening" to recuperate, for philosophy, traditionally feminized modes of affective attention and relation. His theory of affect turns on the appropriation, by a white masculine listener, of traits, attitudes, and comportments stereotypically associated with white femininity. Following the musical metaphor all the way through reveals that Nancy's approach to affect is one version of the well-worn notion of aesthetic receptivity, a concept that values femininity only when it appears in males, only when it dons the trappings of whiteness, and thus continues to marginalize women and non-whites as listeners. So, while Nancy may be philosophically re-valuing affect, he does so in terms that reinforce an underlying patriarchial, Orientalist value structure.

\section{Receptivity and the White Masculine Listener}

In this section, I will first discuss the discourse of aesthetic receptivity generally, and then examine its various manifestations in Nancy's text. Then, I argue that Nancy's appeals to the concept of aesthetic receptivity (a) are grounded in Orientalist, patriarchal stereotypes about nonwhites and women, and (b) presume a white, heteromasculine aesthetic-philosophical subject, and thus preclude women and non-whites from aesthetic and philosophic experience-i.e., from both hearing and listening. By speaking about music only in the abstract, Nancy allows it to reinforce the biases implicit in the very traditions he is trying to revise. 


\section{(a) The Concept of Aesthetic Receptivity}

Aesthetic receptivity is the ability to be profoundly affected and moved by an artwork or a performance, and/or the ability to move others with one's creations or performances. Basically, receptivity is the ability to experience and communicate affect. To be receptive is not to understand a work (to "hear" or "entendre" in Nancy's terms), but to be moved by its affective dimensions (to "listen" or "écouter" in Nancy's vocabulary). According to philosophers such as Kant and Nietzsche, or writers like Norman Mailer, the exigencies of modern life (Enlightenment rationality, the alienation inherent in capitalism, etc.) have impeded our ability to be genuinely receptive to art. Western culture privileges mind over body and power over sensitivity; notably, these privileged characteristics are also stereotypically attributed to white masculinity. So, white males are particularly deficient in their capacity for receptivity. GoodingWilliams describes it as "the male body's estrangement from its power of receptivity" (GoodingWilliams 43). Interestingly, Gooding-Williams' reading of Nietzsche suggests that the white male knower is alienated even from his own "radiation" or "resonance": Zarathustra,

withdraw[s] into himself and assert[s] his heroic will to truth and knowledge, thus appearing to be a shadowy phantom whose essence is suprasensible. Standing aloof from the world of appearances, he seems to reside wholly beyond the reach of warm sunlight, and even beyond the touch and warmth of his own sunlight. (47)

White masculinity, as a practice of hearing and intellectual ability, renders its practitioners insensitive to listening and affect. And not just affect in general, but one's affective awareness of one's own body, emotions, and subjectivity. So, the real impediments to receptivity are normative whiteness and masculinity: whiteness entails a certain distancing from one's body, just as heteromasculinity entails a certain distancing from one's emotions. In order to be affectively open and receptive to art, it is argued that one (a presumably white, male "one") must 
appropriate the modes of attention and bodily comportment stereotypically attributed to (and seen as evidence of inferiority in) women and non-whites.

Because they are associated with corporeality, emotion, and sensual/sensuous enjoyment, receptivity is thought to be a mysterious power that women and non-whites - especially blackspossess in abundance ${ }^{17}$ Gooding-Williams argues that receptivity is both gendered feminine and raced black: "what femininity ... [and] blackness does" for the white, male/masculine subject, is "qualif[y] his masculinity, thus rendering him susceptible to his body's promptings" (58). Nancy's theory of listening, like more traditional discourses of aesthetic receptivity, attempts to rejuvenate philosophy (and the philosopher) by giving it/him access to affect in the from of fetishized patriarchal fantasies about femininity and blackness. While he may re-value affect, Nancy does so in a way that reinforces philosophy's institutionalized whiteness and patriarchy. He opens philosophy to its "other," affect, while keeping the doors closed to those traditionally Other in philosophy.

\section{(b) Receptivity in Nancy}

Nancy argues that the practice of philosophy overemphasizes hearing-understanding (entendre), and thus alienates us from our ability to genuinely and fully listen (écouter). He asks,

rhetorically, "Isn't the philosopher someone who always hears (and who hears everything), but who cannot listen, or who, more precisely, neutralizes listening within himself, so he can philosophize?" (1). As Nancy describes it here, the practice of philosophy requires a certain repression or alienation from the renvoi, the subject/object of listening. For Nancy, philosophyparticularly what is called "the metaphysics of presence"-limits us to the symbolic and alienates us from our capacity to engage perceive/receive the semiotic or affective dimensions of meaning. Listening is "the rejection ... of philosophizing anesthesia" (31). 
If philosophizing anesthesia separates us from our sensitivity to our embodiment, listening restores it to us. "Listening," Nancy explains, "bears in the most ostensive way the perceptible or sensitive (aesthetic) condition as such" (14; emphasis mine). More precisely, this aesthetic "sensitivity" is the condition of being "ope[n] ... to the resonant body, to its vibration" (25). It is "the space in which "I hear myself" (29). Unlike Zarathustra, who is incapable of feeling and being affected by his own "radiance," Nancy's listener is receptive precisely to his own resonance. "Listening opens (itself) up to resonance and that resonance opens (itself) up to the self" (25). Insofar as "openness" (or "passive expectancy") and corporeality are stereotypically feminine traits, to be listening is to have a feminine relationship to the world and to oneself; this feminine comportment thus grants one the capacity to listen, to perceive the renvoi. ${ }^{18}$ Augmenting his masculinity with the feminized power of aesthetic receptivity, the listener, unlike the philosopher, can perceive his own echoes. One treats philosophical anesthesia by appropriating this feminized capacity for re-bound or affect-i.e., receptivity. ${ }^{19}$ Nancy's text performs this appropriation, making implicit and explicit references to stereotypical notions of femininity and blackness.

\section{(c) Feminizing and Blackening Listening}

Nancy often implicitly feminizes listening. I have already discussed several examples of this. Nancy also explicitly feminizes listening. He repeatedly identifies the womb as the privileged site of listening. Noting "the womb [matrice]-like constitution of resonance," Nancy argues "it is always in the belly that we-man or woman — end up listening, or start listening. The ear opens onto the sonorous cave that we then become" (36-7). Here, the uterus is a sort of echo-chamber, an ideally resonant structure. Interpreting Titian's painting Venus, which depicts a male organ player ogling a nude, reclining goddess, Nancy claims that the goddess's "belly" is 
"the very place where his music comes to resound" (45; emphasis mine). ${ }^{20}$ The musician here is male, and he can only really listen by attempting to appropriate or approximate female reproductive organs. ${ }^{21}$ If her uterus is where "the resonance of his instrument" manifests (45), then we should worry that Nancy is being a bit too Aristotelian here, framing women as the passive matter activated by the male seed. If listening is what happens when his music comes to resound in her belly, then listening clearly involves the appropriation and instrumentalization of stereotypical femininity by and for normatively masculine philosophers. In this way, listening is the "becoming-woman" of the male/masculine philosopher.

Nancy's romanticization of hysteria (both the misdiagnosed feminine psychological ailment and the Greek theory of the wandering uterus) further clarifies that listening is a project for a male/masculine discourse and the male/masculine practitioners of that discourse. He argues: "That skin stretched over its own sonorous cavity, this belly that listens to itself and strays away in itself while listening to the world and while straying in all directions ... it is my body beaten by its sense of body, what we used to call its soul" (43; emphasis mine). According to Nancy, when the listening subject has a wandering uterus, he can access new realms of aesthetic experience. This listening subject must be male, because if a woman experiences a "wandering uterus," she is seen as merely hysteric and as not to be taken seriously. ${ }^{22}$ Interestingly, this passage connects the uterus with the drum (stretched skin) and with "soul"both things stereotypically associated with blackness and African cultures. Nancy's discussion of the drum plays into all these unfortunate stereotypes. For example, he describes drumming as a primitive, non-Western practice: "the resonance of a stretched skin (possibly sprinkled with alcohol, the way certain shamans do)" (42; emphasis mine). In order (for the implicitly white, 
European philosopher) to listen, what is needed is people of color and their exotic, unfamiliar cultural practices.

Nancy describes the resonant body as a primitive, undifferentiated body sensitive to perceptual registers to which more advanced subjects and societies are desensitized. To listen is

to treat the body, before any distinction of places and functions of resonance, as being, wholly (and 'without organs'), a resonance chamber or column of beyond-meaning (its 'soul,' as we say of the barrel of a cannon, or of the part of the violin that transmits vibrations between the sounding board and the back, or else of the little hole in the clarinet...); and from there, to envisage of the 'subject' as that part, in the body, that is listening or vibrates with listening to - or with the echo of - the beyond-meaning. $(31)^{23}$

The "body without organs" is a Deleuzian term for an undifferentiated, undeveloped plane of experience. A body "without organs" is untrained, unmarked by culturally-specific disciplines or habits. If the resonant body is "without organs," then listening involves a regression back to a more primitive, less developed state. Nancy implies that listening involves, at least in part, "going native." To listen is to shuck all those advancements and cultural accoutrements that give one access to "meaning," and to regress to a more primitive, more "soulful" state.

Following the canon's tendency to feminize and blacken aesthetic receptivity, Nancy both feminizes and blackens listening. In so doing, he implicitly posits the listener, the person or discourse for whom resonance is a new and revelatory experience, as normatively white and masculine. Insofar as Nancy's theory of listening assumes a normatively white philosopher and contrasts this to either blackness or white femininity, it structurally excludes female and nonwhite people from participating in the activity of "listening" (and philosophy). This structural exclusion is evident not only in Nancy's use of racialized and gendered language, but also in his use of music. Framing listening as a matter of harmony, Nancy's politics of listening is a more or less classically liberal theory of assimilation: in the same way that all overtones are derived from 
a primary tone, "resonance" reduces all political differences to one underlying unity - in this case, hegemonic white masculinity.

\section{Harmony, Assimilation, and Classical Liberalism}

Nancy uses listening and the renvoi as a model for a politics of difference. In particular, he takes Enlightenment and $19^{\text {th }}$ century understandings of musical harmony-e.g., the overtone series, tonal functional harmony — as a metaphor for multicultural belonging. He is basically using Modern concepts of musical harmony as an ideal model for socio-political "harmony." Nancy's theory of listening as resonant unity-in-difference is, as I will show, a version classically liberal assimilationism.

Because Nancy argues that affect or "sense is to be found in resonance, and only in resonance" (7), we need to figure out what, exactly, he means by "resonance." As I discussed above, he does model resonance and the renvoi on the overtone series. Here, I want to unpack the values implicit in this appeal to the overtone series. Even though the overtone series is an objective property of sound, the idea that it is an index of relative consonance or dissonance is not an objective property of sound. The values assigned to the intervals expressed in the overtone series are cultural, as is the notion that the overtone series expresses an ideal organizational rationality. Tonality or tonal harmony is the name of the musical episteme that treats the overtone series as an index of relative consonance and dissonance, and as an ideal organizational rationality. Tonality, like classically liberal political theory, privileges one central term and assimilates everything else to this common denominator.

So, what is tonality, how does it relate to the overtone series, and what do I mean by claiming they treat difference (i.e., dissonance) as something to be assimilated to a primary term? 
Around the same time that Descartes was arguing that free will was a gift from God, and the social contract theorists were figuring out how and why we gave up some of this freedom in return for a little security, music theorists were developing a general system of musical organization based in the overtone series. ${ }^{24}$ In tonality, the structure of a "single" tone was the ideal model for the structure of a whole piece of music, a whole hour-long symphony or threehour long opera. ${ }^{25}$ What is this structure? Overtones always sound in an unvarying series of intervals above the primary tone: an octave, a fifth above that, an octave above that, a fourth above that, and so on. As a theory of music, tonality translates the order of these intervals into a hierarchical measure of relative consonance or dissonance: the octave is the most consonant interval, then the fifth (hence its title "dominant"), the fourth ("subdominant"), etc. The point is that all of these intervals (fifth, fourth) and functions (dominant, subdominant) are indexed to the primary tone (the "tonic"), and assimilable to it. As a compositional strategy, tonality is a system for introducing dissonance-most often in the form of chord changes or key changes — in order to resolve this dissonance back to consonance; every song has to end in the same key (and on the same chord, in the same inversion and octave) in which it began. Tonality instrumentalizes difference-it's what produces interest, what generates the harmonic conflict that the song will resolve. $^{26}$

The overtone series and tonal harmony are logics of internal differentiation and/or assimilation. All overtones are effects of — and thus reducible to - one primary tone, and tonal harmony is a compositional strategy focused on the introduction, exacerbation, and resolution of dissonance into consonance. In the same way, classical liberalism treats "diverse" populations as both reducible to, and instruments in service of, privileged groups. As political philosopher Falguni Sheth explains, 
Western - liberal - society has learned to manage its fear of the strange by controlling the degree and quality of cultural difference that will be tolerated and accommodated...banal cultural differences such as 'exotic' holidays, traditions, or food are insufficient to marginalize a population, since they can be construed as - or transformed into-simple consumer or aesthetic preferences and, in a world marked by global capitalism, welcomed as marks of cosmpolitanism. (71)

Liberal political theories value differences only when they appear in the private sphere (e.g., the market), and punish manifestations of difference in the public sphere. ${ }^{27}$ Though it claims to be tolerant of difference, liberalism makes assimilation to dominant norms a prerequisite for participation in the public sphere-i.e., for receiving the rights and protections one is entitled to as a member of a polity. ${ }^{28}$ In the same way that the tonic or primary tone is the centered and controlling term in music, whiteness, for example, is the centered and controlling term in classically liberal models of diversity and multiculturalism. Difference is fine, on the condition that is in service of and assimilable to whiteness. For example, institutional diversity is often presented as a benefit for whites: being around "different" people exposes an otherwise homogeneous white bourgeoisie to new and interesting ideas, experiences, points of view, etc. Or, more insidiously, this diversity is evidence of whites' moral uprightness-what Sheth calls "marks of cosmopolitanism." 29 Similarly, liberal meritocratic ideals champion equality of opportunity without ever questioning the norms and biases that ground the standards by which success is measured. Difference that is too distant from the white center must be domesticated/assimilated, or eliminated. As Linda Alcoff explains, "the melting pot failed to diminish racial hierarchies because it was never really intended to include different races ... assimilationism and its heir apparent, cultural appreciation, have not led to a true mixing of races or cultures, or to an end to the relations of domination among cultures" (271). This is a spurious 
multiculturalism because it conditions group membership on assimilation, and does not de-center privilege.

How is this assimilative model evident in Nancy? The renvoi is what renders the listener a unique being: one listens to one's own resonance as such, and in so doing recognizes oneself as a "unity of and in diversity" (Nancy 18). As Nancy figures it, the renvoi is a kind of repetition that creates difference, not copies; echoes sound different from one another, and from the sonic event from which they originate. Echoes are, however, ever-so-slightly different versions of the same utterance, like overtones are effects of a single primary tone. The self-referential character of the renvoi means that it frames "otherness" as something ultimately deriving from the "self." What Nancy calls "unity-in-difference" is in fact the internal heterogeneity of the self, not the self's encounter with an Other. For example, Nancy describes "presence 'on the rebound," as being "in a return [renvoi] from one element to the other, whether it be between the emitter and the receptor or in one or the other, or, finally and especially, between the sound and itself" (15). Because, as I discussed above, the resonant subject is both emitter and receptor, the renvoi is a model of self-relation: its "many"-ness comes from "an internal diffraction" (73), not from external differences. Even though the renvoi is a "rebound that does not end in any return to self without immediately relaunching, as an echo, a call to that same self" (21), Nancy argues that there exists, "at the bottom of all this reversion an original, generative repetition, by which the to self occurs" (quotation in Szendy x). Difference, here, is a call addressed to the self-I don't have to, and may not be able to, listen to other people, let alone people who sound significantly different from me, who "resonate" at different frequencies than I do ${ }^{30}$ Difference is something that re-centers the self-same listener, just as tonal dissonances only re-center the tonic as the consonant, primary pitch. Thus, even if Nancy intends for "listening" to be "reopening ... 
beyond agreement or harmony (harmony [entente] or resolution in the musical sense)" (Nancy 32), resonance, the renvoi, is only an opening of the self to itself. Just as overtones all refer back to a primary tone, the renvoi's resonance centers a primary self or listener.

Like a melting-pot, Nancy's renvoi is what music theorists call homophonic: it is the blending or assimilation of different parts into one (homo) main "voice" (phone). In this way, then, the renvoi's supposed "unity-in-difference/difference-in-unity" is, like all liberal accounts of "diversity," ultimately a spurious model of "difference" or "multiculturalism." In the same way that liberal melting-pot multiculturalism continues to center already privileged norms and identities, Nancy's resonant theory of unity-in-difference fails to de-center the self: all encounters with difference occur in my own self, on my own terms. ${ }^{31}$ The renvoi may complicate or compound the traditional philosophical subject, but it does not hybridize him.

In his theory of affective listening, Nancy uses music in a very abstract, metaphorical way. Because he does not contextualize specific musical theories or practices, musical concepts can naturalize culturally-specific epistemes and values, hegemonic subject positions, and power relations - like liberal homophony - that Nancy may otherwise want to avoid. Paying more careful attention to the musical theories and practices assumed in Nancy's concept of listening, we see that the resulting discussions reinforce hegemonic white heteropatriarchy. In Nancy's Listening, affect, femininity, and racial non-Whiteness are still "subaltern" voices in philosophy-like quarter-tones to the diatonically-trained Western ear (which recognizes only whole and half steps as "real" pitches), philosophy cannot hear them as independently legitimate pitches. In the final section, I analyze specific musical works and practices to develop an alternative theory of subjectivity and intersubjectivity, one that does not share classical liberalism's and "classical" tonality's assmiliative, homophonic logic. 


\section{IV. "Acapella" and the Status of Accompaniment}

The lead single from Kelis's 2010 album Flesh Tone, "Acapella" is an electro-pop dance track with lyrics about the then-recent birth of her son. She separated from her longtime partner during her pregnancy, so the lyrics address Kelis's experiences as a black single mother, one of the most demonized social roles in the American political imaginary (Moynihan Report, "welfare queen" stereotypes, etc.). So, the subject positions assumed and centered by Kelis and Nancy could not be more different. More importantly for my purposes here, Kelis's song adopts models of political and musical organization that are very different from the ones Nancy uses and idealizes. Reading “Acapella” against Nancy's notion of resonant listening, I argue that Kelis's musical practice elaborates the alternative political practices she talks about in the lyrics. This political practice is an alternative to classically liberal assimilationism, the spurious multiculturalism that instrumentalizes difference as a way to re-center privileged groups. Difference is necessary, but it is not something to be assimilated, metabolized, or sublated. Taking her uterus as a site of polyphony and polyrhythm rather than (homophonic) resonance, Kelis's "Acapella" performs a model of politics that assumes both interdependence and irreducibility among individuals.

As a musical term, "acappella" refers to the lack of instrumental accompaniment. The lyrics of "Acapella" use the title as an organizing conceit: vocal accompaniment is a metaphor for personal companionship. The song's musical organization, the way it structures musical accompaniment, parallels the way Kelis describes intersubjective accompaniment. Though "Acapella" references the idea of homophony and symphonic resonance, the song itself is not conventionally homophonic or harmonically resonant in Nancy's sense. First I will address the lyrical content of the song, the verbal references to and reworkings of conventional ideas of 
harmony and homphony. Then, I will discuss the song's compositional form-its musical, rather than verbal, content.

\section{(a) Lyrics}

The musical term "acappella" means unaccompanied vocals; it can refer to a single vocalist, or a group of vocalists singing without instrumental accompaniment. The important difference here is between the kind of accompaniment to the vocals: though there are some technical-historical nuances to the way the term is used, in general "acappella" means voices only, no non-human instruments. For example, what are called "acappella" vocal groups perform popular songs - e.g., classic rock, Top-40 R\&B - arranged so that vocal parts cover what were originally instrumental accompaniment. ${ }^{32}$ It's still homophonic (one main melody accompanied by subsidiary parts), and there is still accompaniment, but because there are only voices, no instruments, it's called "acappella." So, to not sing acappella is to practice music with a different species of musical instrument - a piano, a guitar, an ensemble, an 808 and a sampler, etc. Thus, when Kelis sings, "Before you, my whole life was acappella/Now a symphony's the only song to sing," she means that, with the birth of her son, Kelis is no longer living alone, but in concert with an irreducibly different being. ${ }^{33}$ She can no longer conceive of herself as an atomistic, autonomous subject; rather, her subjectivity is better understood as an intersubjective existence. ${ }^{34}$ This other existence cannot be assimilated as another voice; in order for Kelis to not sing acappella, to sing a "symphony," her voice has to be accompanied by a non-vocal instrument. Similarly, a symphony orchestra is composed of strings, woodwinds, brass, and percussionfour very distinct types of instruments. Symphonic singers are interdependent on, but irreducible to, one another. 
Interdependence amid irreducible difference also characterizes the relationships among mothers and children, and pregnant women with their own bodies. The lyrics directly address this sort of corporeal intimacy and interdependence. If singing acappella means "I can't feel your heartbeat, it's just me surviving alone," then symphonic experience includes sensory, affective attunement to the asynchronous rhythm of another person's heart. Because a mother's body will be significantly larger than her foetus's or infant's, their heart rates cannot match tempo: that would be really unhealthy! ${ }^{35}$ With mother and child going at different tempi, this "symphony" is polyrhythmic: their different patterns are interwoven, but irreducible. (Polyrhythm means two or more different meters happening at the same time.) So, the singing Kelis does with her companion(s) neither idealizes unity nor assimilates differences to a common denominator (tempo, time signature, etc.). While the lyrics may use the language of traditional harmonic composition - acappella, symphony, etc.-it resignifies their meaning. The song uses the mother-child relationship to develop an alternative account of subjectivity and intersubjectivity than the ones offered by classical liberal assimilationism. Grounded in her experiences of pregnancy and maternity, Kelis's notion of "accompaniment" is non-assimilative.

\section{(b) Musical Structure}

This method of handling accompaniment is not only expressed in the lyrical content; it is also manifest in the song's compositional form. Unlike tonal and homophonic forms, it uses nonassimilative, non-hierarchical strategies and techniques to organize the song, and to build the tension-release structures that Western ears are acculturated to find pleasurable. While a much more detailed analysis of this song is possible, I want this paper to be maximally accessible to scholars outside music theory and musicology. So, I'm limiting my analysis here to the most clear, narrowly-drawn example. I will focus only on the song's bridge. In a verse-chorus or 
$\mathrm{ABABCB}$ style song, the bridge is the "break", the "C" section, whose contrast builds tension to make the return to the chorus more remarkable and satisfying. In general, the bridge or break is often the most important, compositionally interesting and affectively powerful part of a pop song, and "Acapella" follows this convention. The bridge shows the song's alternative models of accompaniment in their most concentrated forms: it uses (1) polyphony and acappella (monophonic) singing instead of homophony and (2) a tension-release rather than a tensionresolution structure. These techniques create an orderly relation among all the song's parts without requiring either the assimilation of accompanying voices to a primary voice (as in homophony), or the resolution of dissonant chords or key areas to consonant ones (as in tonal harmony).

It is common for rock and pop songs, like "classical" music, to be organized harmonically, around the introduction, development, and resolution of dissonances into consonances. Different parts of the song are defined by changes in keys and chords, and these non-original keys and chords are considered relatively "dissonant" elements; the song ends when it returns back to the original key, back to "consonance." The introduction and development of dissonances creates a sense of "tension"- this is like the "conflict" in a literary narrative. ${ }^{36}$ Thus, there's a sense of pleasure and relief we feel when that conflict is conclusively resolved, usually by reiterating originally dissonant material in more consonant terms (e.g., a melody originally performed in a secondary key will be played in the primary key). Difference/dissonance is literally assimilated to consonance.

Instead of using a tension-resolution structure, "Acapella" uses a tension-release framework. This framework, which music critic Daniel Barrow calls "the Soar," organizes the whole song, but the bridge gives us a microcosm of this overarching structure. ${ }^{37}$ Instead of using 
dissonance to build tension, the Soar creates tension by intensifying rhythmic events, adding more and faster events until the ear almost can't physically differentiate among them; at this point the song usually drops to silence for a beat or a measure, and then returns with a big "hit". Rather than generating dissonance and resolving it into consonance, the Soar builds rhythmic intensity and releases it without resolving it. ${ }^{38}$ This rhythmic intensification, both a mini-Soar and the climax of the large-scale Soar, happens in "Acapella's" bridge. The bridge begins after the second chorus where the rhythmic accompaniment changes and Kelis sings, "You got the drum of my heartbeat, bass and guitar lead/Stuck on the notes you play." She repeats this phrase three times, and each successive repetition is accompanied by an increasingly complex, rhythmically intense instrumental track. Then, there are four bars where the instrumentals drop out entirely, making this the only moment where Kelis actually sings acappella. Instead of assimilating the vocal or instrumental material in the bridge to the 8-bar rhythmic pattern that organizes the rest of the song, the break dissipates in a unique four-measure phrase irreducible to any other part of the song. ${ }^{39}$ So, the rhythmic intensity is not resolved, but released, dissipated into silence. The acappella section feels like a moment of release because it immediately follows a very instrumentally maximalized phrase; so, it is dependent on, but irreducible to, earlier material in the song. In this song, literal acappella singing performs, at the level of musical form, the idea of interdependent-but-irreducible subjectivity expressed in the lyrical content.

The bridge's tension-release structure is one example of "Acapella's" non-assimilative organizational strategies. The bridge's vocal delivery is another example of a system of interdependent-but-irreducible elements. Here, as in rapping or the rap-influenced singing popularized by Mary J. Blige, the vocals function more rhythmically than melodically. Kelis stays more or less exclusively on a single pitch, "stuck," as the lyrics say, "on a note." Because 
there is little pitch variation, the vocals don't create much of a melodic line; rather, the articulations of the words, their meter and emphases, contribute a rhythmic effect. The interest here is not in the pitch(es) Kelis sings, but on the rhythmic patterns made by the words - the patterns of stressed and unstressed syllables, articulations and slurs, etc. So, if the voice is more or less another percussion instrument here, then the texture is not homophonic. In homophony, there is a primary voice (usually the vocals) accompanied by subsidiary voices (the instrumentals). In polyphony and counterpoint, there is no single primary voice. Instead of assimilating the instrumentals to a vocal melody, the bridge is composed of interdependent but irreducible parts. Thus, this polyphonic structure echoes the polyrhythmic metaphor Kelis uses to describe the affective intimacy between mother and child.

Kelis's "Acapella" gives us an alternative to Nancy's theory of resonance. She begins from a different subject position than he does, and develops a different theory/practice of intersubjectivity. Rather than idealizing the womb and speaking of music in the abstract, Kelis's song uses actual maternal bodily experience and actual musical structures as the basis for her concept of subjectivity and intersubjectivity. From this perspective, difference is not a problem that needs a (re)solution, nor is affective intimacy lost and in need of recovery. Rather, both our relation and our separation - to one another, to affect - is always-already assumed: like a mother and her infant child, we are all interdependent but irreducible to one another, or to any common denominator.

\section{Conclusion}

Taking music concretely, and not just metaphorically, points to some of the political problems with Nancy's theory of listening. Both listening and liberal melting-pot 
multiculturalism superficially claim to value difference, but actually posit an imperative to assimilate to whatever has already been established as the norm (e.g., the tonic or root tone). The role of gender, and to a lesser extent, race, in Nancy's elaboration of his concept of listening is further evidence of its assimilative character. Nancy claims that Western philosophy is caught up in intellectualized "hearing-understanding" and has lost its ability to "listen"-i.e., to perceive embodied affect. He feminizes and racially non-whitens affective resonance; if it is something philosophy lacks and must regain, then listening is a problem/project only for white men. His overly-abstract and ahistorical use of musical terms lead him to import into his own work all the patriarchial, Eurocentric baggage that comes with the conventional sense of these concepts.

If we want music to be more than a metaphor that naturalizes hegemonic biases and values, then analyzing actual, concrete musical theories and practices is a necessary, if not entirely sufficient, step in doing philosophy with and through music. To the non-expert, music, like affect, is a largely implicit knowledge: a know-how or habitual understanding that is (and sometimes can) not be formulated in verbal or symbolic propositions. ${ }^{40}$ Because music is organized in non-propositional ways, it is a rich resource for examining implicit biases, affective knowledges, and other forms of non-traditional epistemologies. Analyses of musical structures, practices, and systems of organization can shed light on the cultural, political, epistemic, and ontological/metaphysical aspects of affect and implicit understanding. Such analyses can also be used to examine critiques of and alternatives to hegemonic norms and ideals. My reading of Kelis's "Acapella" is one example of this method. I have shown how the musical elements and strategies in this song depict structures of subjectivity and relationality that are quite different from - and preferable to - the ones in Nancy's Listening. Instead of relying on conventionally homophonic, assimilative organizational strategies, Acapella's lyrics, its compositional form, 
and Kelis's performance choices all portray models of interdependent but irreducible difference. While the song begins from the subject position of a single black mother, it does not end there. Unlike Nancy's listener, who relates to himself, to his own echo, Kelis's voice is neither solipsistic nor homophonically accompanied — she's neither the only voice, nor the central voice. Instead, Kelis participates in what Devonia Havis calls the "black vernacular phenomen[on]" of "withness" (748). In the "oscillation between the requirement to give an individual performance that is relationally supported within a community that also exults in the stylization ... [and] a welcoming, non-totalizing experience of indeterminate Otherness" (Havis 749), "indeterminacy" and inter-determinacy are mutually sustaining. Kelis's musical and political practices, grounded in black vernacular traditions, treat difference not as something to be assimilated, but as the irreducible ground of interdependence.

If music is the Other of philosophy, it is not because it is irrational, but because it follows different logics, uses different epistemic systems. Thus, careful, rigorous attention to actual musical theories and practices can help shake philosophers out of some of our own worst habits and entrenched biases/perspectives. When we analyze and theorize affect, we have to make sure that we're not just hearing our own echoes, or the echoes of the canon transposed into a different key. Working with and from music can help affect studies approach understudied problems in unconventional ways. If only because all the groups that are underrepresented in philosophy (women, people of color, trans and genderqueer people) are relatively well-represented in popular music, philosophers would do well to think with and through pop music, its conventions, techniques, and discourses. $^{41}$ 


\section{Notes}

${ }^{1}$ See Puar, Terrorist Assemblages and "I would rather be a cyborg." In the latter piece, Puar argues that "to dismiss assemblage in favor of retaining intersectional identitarian frameworks is to miss the ways in which societies of control apprehend and produce bodies as information, as matter that functions not or predominantly through signification, as modulation of capacities, as dividuals in populations with any array of diverse switchpoints (rather than Althusserian interpellation per se), and surveilles bodies not on identity positions alone but through affective tendencies and statistical probabilities."

${ }^{2}$ See Alcoff, Visible Identities.

${ }^{3}$ See, for example, Chow and Steintrager.

${ }^{4}$ For example, in the beginning of Chaos, Territory, Art, Elizabeth Grosz cautions readers that the topic of the book is "not the historical, evolutionary, or material origins of art, confirmable by some kind of material evidence or empirical research" (1). She's not talking about artworks; rather, she's using "art" or "music" as metaphors for a particular philosophical approach or process. She is not theorizing from or about music so much as using it as a metaphor for something else. This is the reason she gives for ignoring actual musical practices and works.

${ }^{5}$ I want to clarify that I'm not talking about scholars who work explicitly on the philosophy of music. I am referring to philosophers who refer to music in their analysis of something else, like politics or metaphysics. Philosophers of music tend to know a lot about music, and are often formally trained in its theory and/or practice.

6 As musicologist Christopher Hasty explains, "Because music is judged non-representational, non-denotative, non-mimetic (or, at best, impoverished in these categories), because music does not seem to support the paraphrastic character we so value in the realm of discourse, because we find it difficult or impossible to say exactly what we have heard, music can seem purely subjective, willful, unruly, irrational-generating even from the same or similar stimulus the most fleeting and incommensurate of impressions or emotions" (2).

${ }^{7}$ Polyrhythm is the presence of two or more differently-pulsed rhythmic patterns in the same underlying timeframe. For definitions of specific musical terms, I suggest: Sadie, Stanley and John Tyrrell, or Latham.

8 "Indeed, as we have known since Aristotle, sensing [sentir] is always a perception [resentir], that is, a feeling-oneself-feel [se-sentir-sentir]" (Nancy 8).

9 Nancy explicitly frames hearing as passive ("simple") and listening as active ("attentive") (Nancy 5).

${ }^{10}$ For an account of the role of music in Kristeva's theory of the semiotic, see James. 
11 There are many good guides to the overtone series online-I prefer these because they are accessible to lay audiences. The Wikipedia entry on "Harmonic Series" is a good place for nonexperts to start. For a commonly-cited account of how tonal harmony is derived from the overtone series, see Bernstein.

${ }^{12}$ For more on male artists' attempts to re-masculinize the feminized performance position, see Gottleib and Wald.

${ }^{13}$ Nancy opposes the unidirectional gaze of Lacan to the back-and-forth exchange of sonorous presence (but of course we know that even the visible gaze is never simply unidirectional): "Whereas visible or tactile presence occurs in a motionless 'at the same time,' sonorous presence is an essentially mobile ' at the same time,' vibrating from the come-and-go between the source and the ear, through open space, the presence of presence rather than pure presence. One might say: there is the simultaneity of the visible and the contemporaneity of the audible" (Nancy 16). As Joan Copjec, bell hooks, and others have convincingly argued, this is a grossly inaccurate theorization of the gaze. The object of the gaze frequently exhibits agency and indeed, subjectivity. See Copjec and hooks.

${ }^{14}$ In a footnote to his preface to Peter Szendy's Listen, Nancy makes it absolutely clear that he views the listening subject as a male who appropriates stereotypical femininity in a way that allows his masculinity to remain unquestioned. The evidence is in a reference to Mozart's Don Giovanni: "Just as I am writing these words, Peter Szendy himself discreetly reminds me that Don Giovanni sings 'ascoltando ti sto' [listen]! There it is, then: the echo had preceded me..." (Szendy 145). Nancy suggests here that Don Giovanni is the ultimate listener. It should not be forgotten that Don Giovanni's musical seduction takes the form of his character's use of musical elements/techniques often overtly associated with femininity. Indeed, until he is confronted by the statue (who represents the demands of strict tonal harmony), Don Giovanni refuses to conform to heteropatriarchial sexual and musical norms. In the end, however, we know that the Don chooses patriarchy over the "hellish" relegation to femininity. For more on gender in Mozart's opera, see James.

${ }^{15}$ See Irigaray, Speculum and Freud 74.

${ }^{16}$ Irigaray makes this claim in many ways throughout her work. I will point here to only one example among many. Arguing that women are commodities, Irigaray explains that "commodities thus share in the cult of the father, and never stop striving to resemble, to copy, the one who is his representative. It is from that resemblance, from that imitation of what represents paternal authority, that commodities draw their value-for men" (Irigaray, This Sex 178).

${ }^{17}$ See Gooding-Williams 48-58.

${ }^{18}$ For an account of the role of "passive expectancy" in constructions of white femininity, see Dyer. 
19 Nancy describes resonance as "incorporation...the opening up of a body" (29). Lawrence Zbikowski's critique of the role of the body in Nancy's Listening is quite interesting from a feminist perspective. Zbikowski argues that Nancy's theory of listening maintains the same corporeal "anesthesia" that it supposedly overcomes: "although the body appears throughout Nancy's Listening, its role is invariably that of a symbol rather than that of a full participant in coming to know sense: the body resounds with sound, but it seems to have lost its capacity to listen, to engage with rather than simply accept (or serve as a receptacle for) sound ... As has much of contemporary musicology, Nancy has left the body out of his conception of musical behavior, turning it into an empty shell into which can be poured the passions inspired by sonic phantasmagoria" (Zbikowski 5). An ornament barred from full participation, a mere receptacle, the body occupies the same position in Nancy's Listening that women/the feminine occupy in patriarchy. Claiming that Nancy "grants music significance only by placing it beyond signification" (Zbikowski 17), Zbikowski can be read as demonstrating that Nancy marginalizes music by putting it on a pedestal or romanticizing its difference - a strategy not unfamiliar to feminists and postcolonial theorists. Theorists have called this strategy "upward trivialization": it is so far above or beyond that it verges on irrelevance. Or, perhaps we could put it this way: Insofar as the body refuses or escapes re-masculinization, it remains unavailable to the (masculine) listener.

20 Notably, Nancy's analysis of this painting is in a section titled "Coda." Musically, codas reinforce the concluding cadence. So, if this reading of Titian functions as the "coda," it reinforces the main point of the text. This "coda" emphasizes the gendering of the renvoi, and the normatively masculine subject position of the listener; thus, we can take this to be one of the main text's key themes.

${ }^{21}$ Nancy continues, saying, "What is the belly of a pregnant woman, if not the space or the antrum where a new instrument comes to resound, a new organon, which comes to fold in on itself, then, to move, receiving from outside only sounds, which, when the day comes, it will begin to echo through its cry?" (37). I want to object to Nancy's claim that the foetus (or uterus) receives "only sound" from the "outside," because this diminishes the role of the woman who is carrying the pregnancy. The uterus is not some self-sufficient, modular component of a woman's body: her whole body is involved in contributing to, supporting, and maintaing her pregnancy. As are her behaviors: what and how much she eats, exercises, abstains from (smoking, drinking) all impact the pregnancy. The mother's body is a filter through which the outside world is transmitted to the foetus. So, "sounds" might be the only things that get to the foetus without first being (too) filtered by/through the mother's body, but they are not the only external influence on the contents of a woman's uterus.

22 As Christine Battersby and others have demonstrated, it is quite common in philosophical aesthetics for male subjects to be praised for appropriating the very same stereotypically "feminine" traits (like hysteria, or sensitivity to affect, or irrationality) that, when exhibited by women, are considered not praiseworthy, but pathological. See Gender and Genius and The Sublime. 
${ }^{23}$ I am surprised that Nancy identifies the "body without organs" with clarinet finger holes, because wind instruments require the precision of industrial manufacturing to guarantee accuracy and consistency of pitch from instrument to instrument. Prior to machine technology, only wind instruments made by the same craftsperson, as part of the same "family" or set of instruments, could be played together. Wind instruments appeared in larger ensembles only after manufacturing technology had advanced to a level where consistency could be guaranteed. So it seems that the holes on a clarinet are given lots of careful attention; they are far from the "beyond meaning" of the body-without-organs.

${ }^{24}$ Classic texts on tonal harmony include work by Rameau and Schenker.

${ }^{25}$ I discuss why the overtone series was considered the ideal model for musical organization in my book The Conjectural Body (2010).

${ }^{26}$ For more on the politics of tonal harmony, see McClary, Leppert and McClary, and Abbate.

27 For example, Marx's distinction between "political emancipation" and "real human emancipation" is one way of explaining liberalism's relegation of "difference" to the private sphere.

${ }^{28}$ For more thoroughly developed versions of this critique of liberal multiculturalism, see Sheth and Alcoff, Visible. For example, Sheth argues that even though "liberalism, theoretically or as a self-identification of a society, is predicated on the accommodation of ethnic, racial, political, or sorts of diversity or pluralism," this accommodation works in ways that are, in effect, "intrinsically exclusionary" (13-14).

${ }^{29}$ This white-centric approach to multiculturalism is what Linda Alcoff critiques as the "Dances With Wolves" paradigm: "In the movie Dances with Wolves (1991), Kevin Costner plays a Union soldier stationed on the Indian frontier who undergoes a political transformation. He comes to realize that the native peoples his militia intends to kill are not the uncivilized heathens they were portrayed to be, and in fact have a rich civilization in many ways superior to his. Thus, he realizes he is fighting on the wrong side. The remainder of the movie chronicles his struggle to figure out what this realization means for him" ("White People" 262). Costner's character remains the narrative center of the film, and the Native American characters are merely instruments for his protagonist's moral development. See also Thompson.

30 As Alcoff explains, "White attempts to appropriate black culture...seeks to incorporate the Black look within oneself. In other words, attempts by whites to assimilate to blackness may be motivated by the desire to make the Black Look - or Black subjectivity, which is what the Look signifies_-safely internal and thus nonthreatening to the self' (Visible Identities 276).

${ }^{31}$ I am not the first to make the connection between liberalism, "harmonic" models of unity-indifference, and Western accounts of racial/ethnic difference. Jacques Attali's influential work on music and politics (1977's Bruits) argues that harmony is the idea that there is a single axis upon which everything is hierarchically organized. The overtone series is one such axis, but "reason" 
and "humanity" are other "harmonic" ideas. As Christopher Hight notes, $18^{\text {th }}$ - and $19^{\text {th }}$-century theories of race were also "harmonic": racial identity was measured on a continuum of whiteness. See Attali and Hight.

${ }^{32}$ This nomenclature is used, for example, in the NBC series "The Sing Off."

${ }^{33}$ Though it is often a mistake to conflate a song's narrator with its singer (and treat the lyrics as direct or truthful expressions of the singer's own personal self), in the case of this particular song, the narrator is more or less closely based on Kelis's own personal experiences, ideas, and feelings. Because, for example, the album includes a track titled "Song for the Baby," and "the baby" appears in the Acapella video, we can reasonably infer that Kelis's own pregnancy and maternity at least inspired the lyrics, even if they aren't always truthfully represented in the lyrics.

34 Many feminist philosophers have discussed the way pregnancy and motherhood challenge Enlightenment notions of autonomous subjectivity. See especially Julia Kristeva, Luce Irigaray, and Iris Marion Young.

35 Interestingly, though, foetus and young infant heartrates are generally in the 120bpm range, which is a standard dance track tempo.

${ }^{36}$ Fred Maus discusses the use of literary narrative as a metaphor or device for understanding music in "Music As Narrative."

37 Briefly, here is the large-scale organization: The song plays around with a tension between groupings of 3 and groupings of 2-multiples $(2,4,8)$. The intro and the choruses are each two repetitions of an 8-measure phrase (which break down into two four-bar phrases). The verses are the same structure (two repetitions of the 8-bar phrase) plus an extra four bars (so, half an eightbar phrase, which is not repeated). The break is twelve bars total, three repetitions of a fourmeasure phrase that is not related to the 8-bar phrase used in the verses and choruses. The final chorus is three repetitions of the eight-bar phrase. So there's the interplay between threegroupings and four-groupings, but it is not clear that one type decisively wins out over the other.

38 Resolution means domesticating deviant material, returning to the original key in some significant way; release does not return to or reaffirm the central status of the privileged term; unlike Lot's wife, it does not "look back," so to speak, but marches onward.

39 The song is basically the continual looping of one eight-bar drum machine phrase; you can hear it twice in the introduction, before any vocals come in. The verses repeat this phrase twice, with one four-bar phrase at the end to transition to the chorus, which is also two repetitions of the eight-bar phrase. So, the underlying framework is not harmonic-it's not keys or chord changes - but rhythmic; the song is built on a loop.

${ }^{40}$ For more on implicit understanding, see Shotwell. 
${ }^{41}$ I want to emphasize the with (in the sense of being-with, or cooperation) here, because it is important that the subaltern voices in pop music not be appropriated by white philosophy/philosophers and assimilated to the discipline. Rather, these musicians and musical works need to be treated with equal respect, rigor, and attention as the philosophical canon. These performers and their works need to be taken as critical interventions in the discipline or canon, not supplements to be conveniently appropriated when they reinforce already-established norms.

\section{Works Cited}

Abbate, Carolyn. Unsung Voices. Princeton University Press, 1996.

Alcoff, Linda. Visible Identities: Race, Gender, and the Self. Oxford: Oxford University Press, 2005.

—. "What Should White People Do?" Decentering the Center. Eds. Uma Narayan and Sandra Harding. Bloomington: Indiana University Press, 2000. 262-282.

Attali, Jacques. Noise: The Political Economy of Music. Trans. Brian Massumi. Minneapolis: University of Minnesota Press, 1985.

Barrow, Daniel. “A Plague of Soars.” TheQuietus.com. The Quietus. 13 Apr. 2011. Web. 18 July 2012.

Battersby, Christine. "Stages on Kant's Way: Aesthetics, Morality and the Gendered Sublime" Feminism and Tradition in Aesthetics. Eds. Peggy Z. Brand and Carolyn Korsmeyer. University Park: The Pennsylvania University Press, 1995. 88-114.

—. Gender and Genius. Bloomington: Indiana University Press, 1989.

- The Sublime, Terror and Human Difference. London and New York: Routledge, 2007.

Bernstein, Leonard. The Unanswered Question: Six Talks at Harvard. Cambridge, MA: Harvard University Press, 1976.

Chow, Rey and James Steintrager, eds. differences, Special Issue: Sense of Sound 22, no. 2 (2011).

Clément, Catherine. Opera: The Undoing of Women. Trans. Betsy Wing. Minneapolis: University of Minnesota Press, 1988.

Copjec, Joan, "The Orthopsychic Subject: Film Theory and the Reception of Lacan." October, no. 49, (Summer, 1989): 53-71. 
Du Bois, W. E. B. The Souls of Black Folk. New York: Signet, 1995.

Dyer, Richard. White. London: Routledge, 1997.

Freud, Sigmund. "Femininity." New Lectures on Psycho-Analysis: The Standard Edition of the Complete Psychological Works of Sigmund Freud. Ed. James Strachey. London: Hogarth Press, 1953-74. SE xxii, 112-35.

Gilroy, Paul. The Black Atlantic. Cambridge, MA: Harvard University Press, 1993.

Gooding-Williams, Robert. Look, A Negro! New York: Routledge, 2006.

Gottleib, Joan and Gayle Wald. "Smells Like Teen Spirit: Riot Grrrls, Revolution and Women in Independent Rock." Microphone Fiends: Youth, Music and Youth Culture. Ed. Andrew Ross and Tricia Rose. New York: Routledge, 1994. 250-274.

Grosz, Elizabeth. Chaos, Territory, Art. New York: Columbia University Press, 2008.

Hasty, Christopher. "The Image of Thought and Ideas of Music." Sounding the Virtual: Gilles Deleuze and the Theory and Philosophy of Music. Eds. Brian Hulse and Nick Nesbitt. London: Ashgate, 2010: 1-22.

Havis, Devonya N. "Blackness beyond witness." Philosophy and Social Criticism, 35, no. 7 (September 2009): 747-759.

Hight, Christopher. "Stereo Types: The Operation of Sound in the Production of Racial Identity." Leonardo 36, no. 1 (2003): 13-17.

hooks, bell. "The Oppositional Gaze." Black Looks: Race and Representation. Boston: South End Press, 1999. 115-132.

Irigaray, Luce. Speculum of the Other Woman. Trans. Gillian C. Gill. Ithaca, NY: Cornell University Press, 1985.

1985. This Sex Which Is Not One. Trans. Gillian Gill. Ithaca, NY: Cornell University Press, 1985.

James, Robin. "The Musical Semiotic: Kristeva, Don Giovanni, and Feminist Revolt." Philosophy Today 46, no. 5 (2002): 113-119.

- The Conjectural Body: Gender, Race, and the Philosophy of Music. Lanham, MD: Lexington Books, 2010.

Latham, Alison, ed. The Oxford Companion to Music. New York: Oxford University Press, 2002. 
Leppert, Richard and Susan McClary, eds. Music and Society: The Politics of Composition, Performance and Reception. Cambridge: Cambridge University Press, 1987.

Kristeva, Julia. "Women's Time." Trans. Alice Jardine and Harry Blake. Signs 7, no.1 (Autumn 1981): 13-35.

Marx, Karl. "On the Jewish Question.” The Marx-Engels Reader. Ed. Robert C. Tucker. New York: W.W. Norton \& Company, 1978. 26-52.

Maus, Fred. "Music As Narrative.” Indiana Theory Review 12 (1991): 1-34.

McClary, Susan. Feminine Endings: Music, Gender, and Sexuality. Minneapolis: University of Minnesota Press, 1991.

Mulvey, Laura. "Visual Pleasure and Narrative Cinema." Film Theory and Criticism: Introductory Readings. Eds. Leo Braudy and Marshall Cohen. New York: Oxford University Press, 1999. 833-44.

Nancy, Jean-Luc. Listening. Trans. Charlotte Mandell. New York: Fordham University Press, 2007.

Plato. Phaedo. Trans. G. M. A. Grube. Indianapolis, IN: Hackett, 1977.

Puar, Jasbir. Terrorist Assemblages: Homonationalism in Queer Times. Durham: Duke University Press, 2007.

Puar, Jasbir. "I would rather be a cyborg than a goddess." eipcp (January 2011) n. pag. Web. 13 July 2012.

Rameau, Jean-Phillipe. Treatise on Harmony. New York: Dover Books, 1971.

Sadie, Stanley and John Tyrrell, eds. The New Grove Dictionary of Music and Musicians. 2nd ed. London: Macmillan Publishers, 2001.

Said, Edward. Orientalism. New York: Vintage Books, 1979.

Schenker, Heinrich. Free Composition. New York: Pendragon Press, 2001.

Sheth, Falguni. Toward a Political Philosophy of Race. Albany: SUNY Press, 2009.

Shotwell, Alexis. Knowing Otherwise. State College: Penn State University Press, 2011.

Szendy, Peter. Listen: A History of our Ears. Trans. Charlotte Mandell. New York: Fordham University Press, 2008. 
Thompson, Audrey. "Tiffany, Friend of People of Color." International Journal of Qualitative Studies in Education 16, no. 1 (January 2003): 7-29.

Zbikowski, Lawrence M. "Listening to Music." Draft, to appear in Speaking of Music. Eds. Keith Chapin and Andrew Clark. Bronx: Fordham University Press. Web. 13 Sept. 2012. 